\title{
Structural performance of the church of São Miguel de Refojos
}

\author{
Rafael Ramírez; Nuno Mendes; Paulo B. Lourenço \\ ISISE, University of Minho, Guimarães, Portugal
}

Contacting author: rafael.alvarezdelara@gmail.com

\begin{abstract}
This paper addresses the study of the structural stability of the church of São Miguel de Refojos, in Cabeceiras de Basto (Portugal). The building presents low to moderate structural damage, as well as other non-structural problems mainly related to the high presence of water. The work is divided into three main tasks, namely inspection and diagnosis of the building, preparation and calibration of a numerical model, and finally, structural analysis. The structure nonlinear behavior is evaluated and pushover analyses are used to assess the seismic performance. In addition, the stability of the church for horizontal actions is verified by means of limit analysis. The results are evaluated in terms of capacity curves, deformation, structural damage patterns and collapse mechanisms. The present study allowed to obtain detailed and reliable knowledge of the conservation state and structural safety of the historical church.
\end{abstract}

Keywords: Historical structure, masonry, damage, assessment, FE model, pushover, limit analysis.

\section{Introduction}

\subsection{Brief description of the church}

The church of São Miguel de Refojos is a monumental building in Baroque-Rococo style and belongs to the historical Benedictine Monastery located in Cabeceiras de Basto, Portugal. Although the monastery dates back to the 12th century, the current aspect of the building is the result of the renovation works carried out between 1675 and $1766[1,2]$ The church has a Latin-cross plan and consists of the nave, transept and chancel. The crossing is covered by a dome with an oval-shaped plan standing over pendentives. The body of the dome is made up by a drum, a cupola and a lantern. In plan, the building is about $60 \mathrm{~m}$ long and $24 \mathrm{~m}$ wide in the transept. The interior height of the church is about $18 \mathrm{~m}$ in the nave, $35 \mathrm{~m}$ in the central dome and $16 \mathrm{~m}$ in the chancel. The main façade has two bell towers with square plan and about 40 meters high (Figure 1). The walls of the church consist of stone (granite) masonry with variable thickness $(0.85 \mathrm{~m}$ to $2.20 \mathrm{~m})$.

Inside the church, the main entrance is covered by a choir loft supported by a ribbed vault. At one and the other side of the nave and chancel, adjacent lateral bodies are used to accommodate different ecclesiastical functions. The transept connects with a chapel located outside the main body of the church. This chapel has an octagonal plan and is about $8.50 \mathrm{~m}$ high. In the crossing, four granite arches support the dome structure. The ceilings of the nave, transept and chancel are made up by barrel vaults, and above the vaults, these spaces are covered by gable roofs with ceramic tiles finish. The roofs are supported by a timber truss structure oriented in the shortest span. Due to access limitations, only the extrados of the vault and roof structure of the nave could be inspected. 


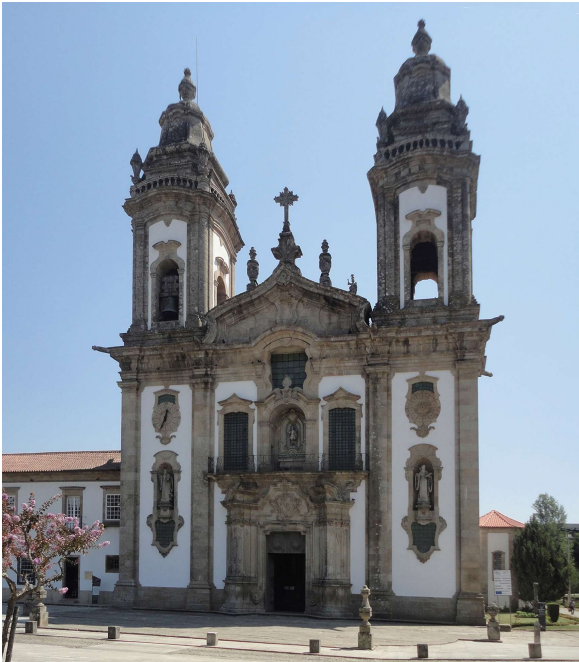

Figure 1. Main façade of the church (West)

\subsection{Main conclusions of the diagnosis}

A comprehensive inspection campaign was recently carried out in order to define the state of conservation of the building [3]. The works included visual inspection, damage survey, monitoring of temperature and humidity inside the church, dynamic identification tests, georadar readings, geotechnical survey (SPT and LDP tests), inspection trenches next to the base of the walls, and water table assessment. The diagnosis made possible to identify both structural and nonstructural problems. The non-structural damage corresponds to moisture stains, vegetation, fungi and deterioration of plaster and stone. On the other hand, the building presents low to moderate structural damage. There are cracks at the top of the south façade, on the transept walls, on the walls behind the high altar, and on the arch between the crossing and the chancel. The most significant damage occurs in the connections between the main façade (West) and the south tower, and in between this tower and the south wall of the nave. Moreover, the open cracks lead to rainwater infiltration with the subsequent deterioration of the internal structures. The floors of the high altar and the octagonal chapel present significant deformations probably caused by consolidation of the soil. Similarly, other deformations in the structure may be associated with a foundation settlement. Although it was not possible to identify the depth of the foundations, the geotechnical survey allowed to identify the geological profile. The superficial layer is constituted by soft clay, little resistant and very deformable, until a depth of about $4.00 \mathrm{~m}$. The following layer corresponds to a transition layer of gravelly sand. The last layer of the soil consists of highly altered and fractured rock (starting at depths between 4.20 to $5.50 \mathrm{~m}$ ). Finally, the diagnosis allowed to verify that the water table is very close to the ground level of the church.

\section{Numerical model}

\subsection{Preparation and calibration of the model}

The numerical Finite Element model of the church was prepared using the structural analysis software DIANA (DIsplacement ANAlyser) [4]. The geometry of the $3 \mathrm{D}$ model included all major structural elements (Figure 2). The stiffness of the elements of the monastery adjacent to the church (orthogonal walls and columns of the cloister) was considered in the model by means of spring elements. An overall base level was assumed for all the walls, located at $-2.00 \mathrm{~m}$ below the nave floor level. The foundation was considered rigid. Thus, all degrees of freedom at the base of the masonry walls were restricted. Since it was not possible to inspect the roofs of the transept and the chancel, the truss elements in these areas were idealized according to the known roof structure above the nave.

The visual inspection and georadar tests allowed to identify the different types of materials that constitute the structure of the church [3], namely brick masonry (vaults), ashlar masonry (walls behind the high altar, arches in the crossing, top part of the towers and dome), three-leaf stone masonry (main walls and rest of masonry elements), granite units (lintels) and timber (roof truss structure). Figure 3 shows the material distribution considered in the model. Initially, the values for the linear properties of materials were defined according to data and recommendations available in specialized literature [5-7].

In addition to the self-weight of the modeled structural elements, the model also included the weights of the roof and the infill material of the vaults. The weight of the roof was assumed equal to $1.00 \mathrm{kN} / \mathrm{m}^{2}$ and it was applied as a uniformly 
distributed load along the timber elements. The infill material was considered up to half the height of the vaults and its weight was estimated equal to $12 \mathrm{kN} / \mathrm{m}^{3}$. The filling material was modelled as a distributed superficial load applied to the extrados of the vaults, near the supports.

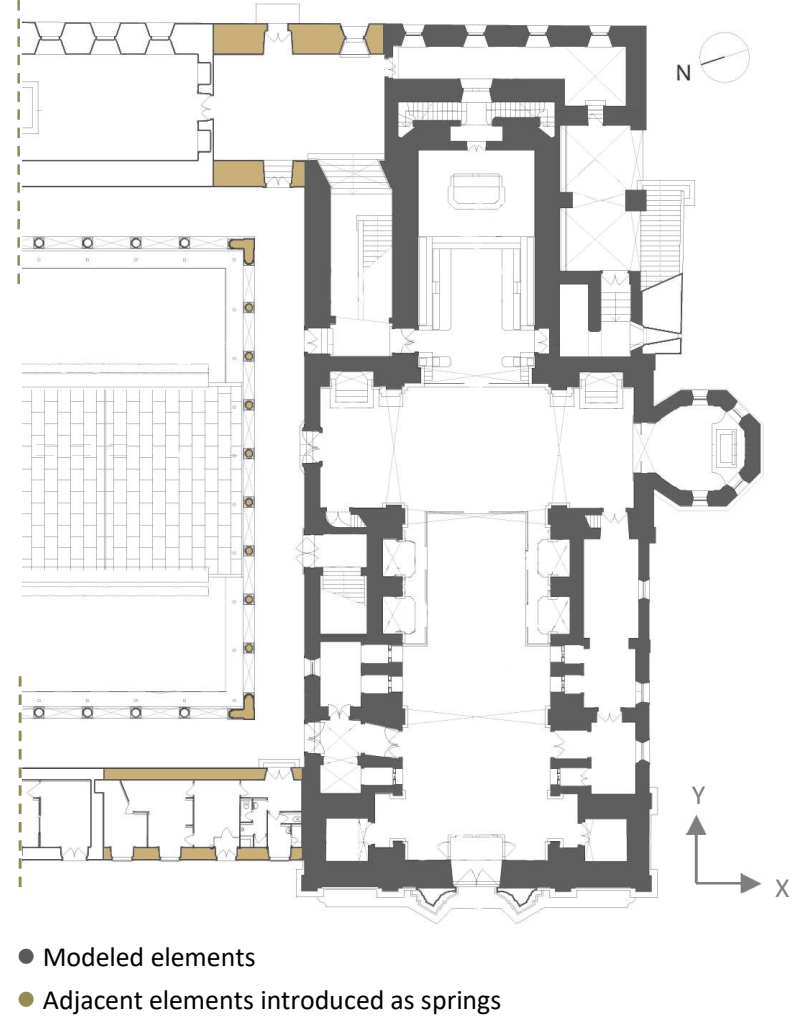

Figure 2. Plan view with the geometry considered for the numerical model. Adapted from [8]

Different types of elements were used for the mesh: solid elements (walls, arches and columns), shell elements (vaults), beam elements (roof trusses) and spring elements (stiffness of adjacent buildings).

The numerical model was validated with respect to the experimental dynamic properties estimated from the dynamic identification tests [3], namely the frequencies of the first three modes of vibration. The calibration was performed following the Douglas-Reid method [9] and using the modulus of elasticity of the different types of masonry as calibration variables. After the optimization process, the numerical model was able to simulate the first three experimental modes of the church with an average error of the frequency values less than $2 \%$. Moreover, the mode shapes of the numerical model were compared with the modal configurations of the experimental modes through MAC (Modal Assurance Criterion) values [10]. In a range from 0 to 1 , where 1 indicates a perfect match of the mode shapes, the calibrated model of the church resulted in an average MAC value equal to 0.92 . Therefore, it is assumed that the numerical model successfully represents the structural behavior of the church and it is possible to use the updated material properties for further analyses.

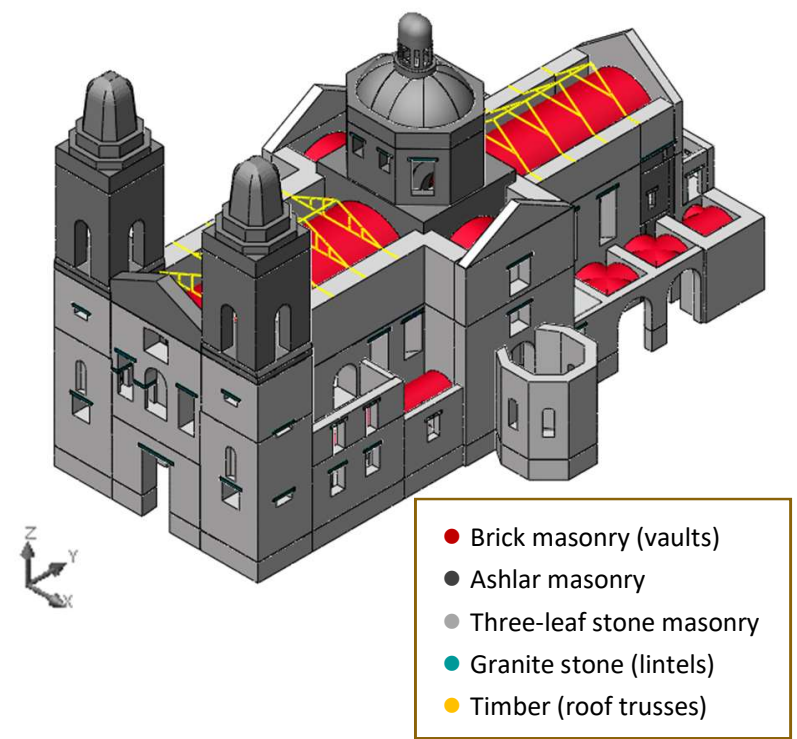

Figure 3. Geometry of the numerical model with identification of materials. Adapted from [8]

\subsection{Material properties}

The nonlinear behavior of masonry was represented using the Total Strain Crack Model, which corresponds to a smeared crack model based on the principal strains [4]. An exponential function was considered for the tensile behavior and a parabolic curve was assumed for compression. In this material model, the shear behavior is updated according to the damage occurred during the analysis. The compressive strength $\left(f_{c}\right)$ was determined as a function of the modulus of elasticity $(E)$, where $f_{c}=E / 600$ [11]. In turn, the compression fracture energy was determined as a function of the compressive strength and the ductility index $\left(d_{u, c}\right)$, where $d_{u, c}=G_{c} / f_{c}$ and $d_{u, c}=1.6 \mathrm{~mm}$ [12]. The tensile strength and tensile fracture energy of masonry were considered equal to $0.15 \mathrm{MPa}$ and $50 \mathrm{~N} / \mathrm{m}$, respectively [13]. Table 1 presents the updated 
Table 1. Linear-elastic and nonlinear properties of materials

\begin{tabular}{cccccccc}
\hline Material & $\begin{array}{c}\text { Density } \\
(\rho)\end{array}$ & $\begin{array}{c}\text { Young's } \\
\text { modulus } \\
(E)\end{array}$ & $\begin{array}{c}\text { Poisson's } \\
\text { ratio } \\
(v)\end{array}$ & $\begin{array}{c}\text { Compressive } \\
\text { strength } \\
\left(f_{c}\right)\end{array}$ & $\begin{array}{c}\text { Compressive } \\
\text { fracture } \\
\text { energy } \\
{\left[\mathrm{kg} / \mathrm{m}^{3}\right]}\end{array}$ & $\begin{array}{c}\text { Tensile } \\
\text { strength } \\
\left(f_{t}\right) \\
{[\mathrm{MPa}]}\end{array}$ & $\begin{array}{c}\text { Tensile } \\
\text { fracture } \\
\text { energy }\end{array}$ \\
\hline Brick masonry & 1800 & 1360 & 0.20 & 2260 & 3.60 & 150 & 0.05 \\
\hline $\begin{array}{c}\text { Three-leaf } \\
\text { stone masonry }\end{array}$ & 2000 & 1620 & 0.20 & 2700 & 4.30 & 150 & 0.05 \\
\hline Ashlar masonry & 2100 & 1900 & 0.20 & 3160 & 5.05 & 150 & 0.05 \\
\hline Granite & 2500 & 30000 & 0.20 & - & - & - & - \\
\hline Timber & 600 & 13000 & 0.30 & - & - & - & - \\
\hline
\end{tabular}

linear and nonlinear properties of the materials used in the model. It must be noted that the granite and timber elements were assumed to work always in the linear elastic range. Finally, the crack bandwidth value $(h)$ was determined according to the type of element, namely $h=$ $\sqrt{2 A}$ and $h=\sqrt{3 V}$ for shell and solid elements, respectively, where $A$ and $V$ stand for the area and volume of the element.

\section{Numerical analysis}

\subsection{Pushover analysis for the seismic action}

The structural performance of the church for the seismic action was evaluated using nonlinear static (pushover) analysis. This type of analysis allows the evaluation of the nonlinear behavior by applying the action in successive load steps. The equilibrium of the system of equations for each step is guaranteed by an iterative method and a convergence criterion. In this case, the regular Newton-Raphson iterative method and an energybased convergence criterion $\left(10^{-3}\right)$ were used. In addition, the Line Search algorithm and arc-length method were used as well to improve the convergence and obtain the post-peak response. The pushover analyses were carried out using a unidirectional loading pattern based on horizontal forces proportional to the mass of the structure [14].

The seismic performance of the building was evaluated according to the global horizontal axes, $X$ and $Y$, which correspond to the transversal and longitudinal directions of the church, respectively. It should be noted that the analysis in the negative transversal direction $(-\mathrm{XX})$ was neglected due to the presence of the adjacent cloister and buildings introduced in the model as spring elements, thus providing larger capacity in that direction.

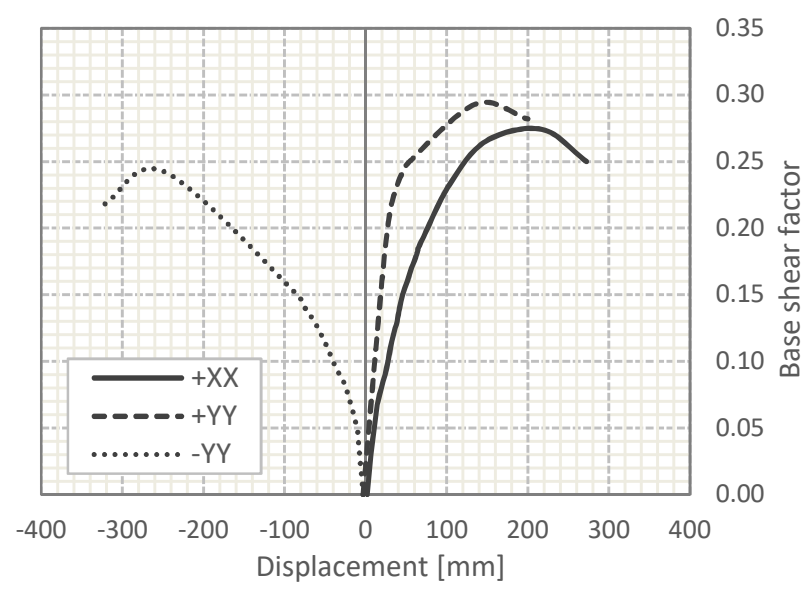

Figure 4. Capacity curves for pushover analyses. Control point at the top of the south tower 


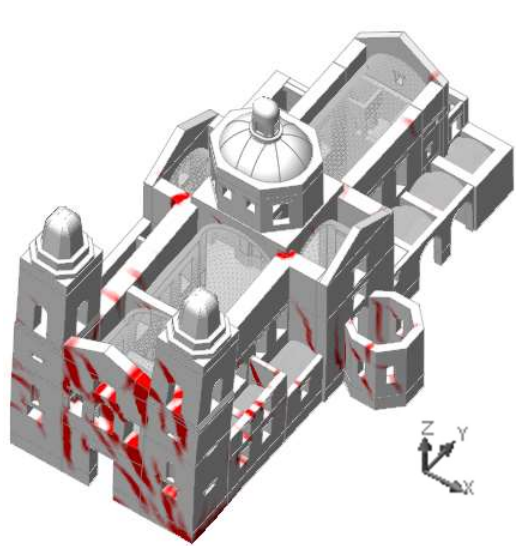

(a)

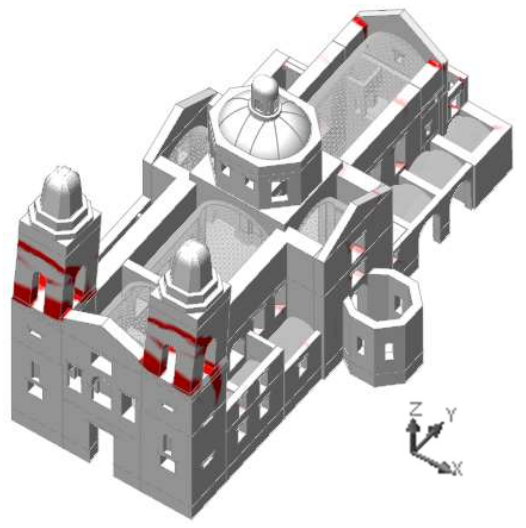

(b)

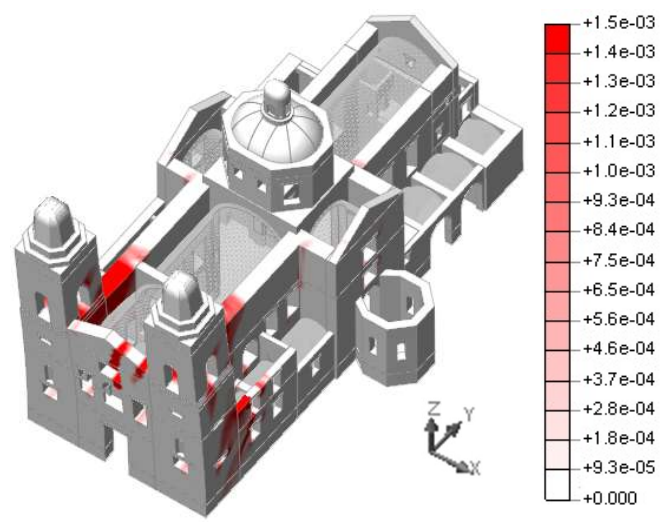

(c)

Figure 5. Crack width associated with the maximum principal strain at the end of the capacity curve for pushover analysis: (a) $+X X$; (b) $+Y Y$; (c) -YY. (Units: $m$ )

\subsubsection{Positive transversal direction (+XX)}

The seismic analysis in the positive transversal direction $(+\mathrm{XX})$ indicates that the maximum horizontal capacity is equal to $0.28 \mathrm{~g}$ (Figure 4). The horizontal maximum displacement occurs at the top of the south tower. The damage pattern is characterized by shear cracks in the plane of the walls and cracks in the connections between structural elements (Figure 5a). The most severe damage occurs in the main façade (diagonal cracks) and in the connections of the south tower with the orthogonal walls.

\subsubsection{Positive longitudinal direction (+YY)}

The capacity curve, with displacement control at the top of the south tower, indicates that the maximum capacity of the church in the positive longitudinal direction is equal to $0.29 \mathrm{~g}$ (Figure 4). The maximum displacement occurs at the top of the towers. In fact, the main failure involves the local collapse of the belfries (Figure $5 b$ ). In addition, there is also damage in the connections between the rear façade and the longitudinal walls of the chancel.

\subsubsection{Negative longitudinal direction (-YY)}

The pushover analysis in the negative longitudinal direction (-YY) presents a maximum base shear factor equal to $0.24 \mathrm{~g}$ (Figure 4). This value represents the lowest capacity obtained from the different pushover analyses, and therefore indicates the most vulnerable direction of the church. This response is associated with a significant deformation of the main façade and the towers in the out-of-plane direction (Figure 5c). The damage pattern is characterized by cracks in the connections between the towers and the longitudinal walls of the nave as well as vertical cracks in the main façade.

\subsection{Safety assessment}

The verification of the structural safety for the seismic action was carried out according to the Eurocode 8 and the National Annex [15]. The verification must be done for each type of seismic action, i.e. Type 1 (far field) and Type 2 (near field), in both principal directions of the structure.

According to the Portuguese seismic zonation, the reference acceleration values $\left(a_{g R}\right)$ for Cabeceiras de Basto are $0.05 \mathrm{~g}$ and $0.08 \mathrm{~g}$ for earthquakes Type 1 and Type 2, respectively. Moreover, the soil coefficient $(S)$ is assumed equal to 1.00 (deep foundations on rock) and the damping correction coefficient $(\eta)$ is equal to 1.00 (5\% damping).

The capacity required in terms of horizontal acceleration is determined as a function of $a_{g R}$, assuming collapse mechanisms based on macroblocks and defined taking into account the damage obtained from the FEM analyses. As presented in Table 2, the results of the pushover analyses for the seismic action indicate that the church meets the required criteria for both types of earthquake. The lowest capacity of the church occurs for the seismic action in the negative longitudinal direction $(0.24 \mathrm{~g})$ and is associated with a safety factor equal to 3.00 . 
Table 2. Safety verification for seismic action by means of nonlinear static analysis

\begin{tabular}{cccc}
\hline \multirow{2}{*}{ Direction } & $\begin{array}{c}\text { Max. } \\
\text { capacity } \\
\end{array}$ & \multicolumn{2}{c}{ Required capacity (g) } \\
\cline { 3 - 4 } & $\mathbf{g})$ & Type 1 & Type 2 \\
\hline$+X X$ & 0.28 & 0.05 & 0.08 \\
\hline$+Y Y$ & 0.29 & 0.05 & 0.08 \\
\hline$-Y Y$ & 0.24 & 0.05 & 0.08 \\
\hline
\end{tabular}

\section{Limit analysis}

In order to validate the seismic performance of the church, a kinematic approach was adopted as well. For the limit analysis, seven local collapse mechanisms were proposed taking into account the damage patterns caused in churches by past earthquakes [16], as well as the results from the pushover analyses and the existing damage in the structure. The stability for each mechanism was verified according to the methodology defined in the Italian code NTC-08 [5,17], in which the following criteria should be evaluated for the Ultimate Limit State:

a) Verification A. Mechanisms involving part of the structure in contact with the soil:

$$
a_{0}^{*} \geq \frac{a_{g} \cdot S}{q}
$$

b) Verification B. Mechanisms involving part of the structure above the ground level:

$$
a_{0}^{*} \geq \frac{S_{e}\left(T_{1}\right) \cdot \psi(Z) \cdot \gamma}{q}
$$

where $a_{0}^{*}$ corresponds to the spectral acceleration for activation of the mechanism, $a_{g}$ is the peak ground acceleration $(0.05 \mathrm{~g}$ and $0.08 \mathrm{~g}$ for earthquake Type 1 and Type 2, respectively), $S$ is the soil coefficient (1.00), $q$ is the behavior coefficient (2.00), $S_{e}\left(T_{1}\right)$ is the spectral acceleration associated with the period $T_{1}$ (first mode of vibration of the structure in the considered direction), $\psi(Z)$ is the ratio between the height of the barycenter of the collapse block divided by the total height, and $\gamma$ is an amplification factor that takes into account the number of floors.
The spectral acceleration of activation for the mechanism is determined by:

$$
a_{0}^{*} \geq \frac{\alpha_{0} \cdot g}{e^{*} \cdot F C}
$$

where $g$ is the acceleration of gravity $\left(9.81 \mathrm{~m} / \mathrm{s}^{2}\right)$, $\alpha_{0}$ is the load factor that activates the mechanism (determined by the Principle of Virtual Works for the equilibrium between the overturning moment caused by the horizontal forces and the stabilizing moment caused by the vertical forces), $F C$ is the confidence factor associated to the level of knowledge of the structure ( 1.00 for $L C=3$ ), and $e^{*}$ corresponds to the mass participation factor of the mechanism:

$$
e^{*}=\frac{g \cdot M^{*}}{\sum_{i} P_{i}}
$$

where $M^{*}$ is the mass participation of the mechanism:

$$
M^{*}=\frac{\left(\sum_{i} P_{i} \delta_{x, i}\right)^{2}}{g \cdot \sum_{i} P_{i} \delta_{x, i}{ }^{2}}
$$

$P_{i}$ is the vertical force of the self-weight and $\delta_{x, i}$ is the horizontal virtual displacement of the center of gravity of the macroblock $i$.

In the studied case, the masonry was assumed to have infinite compressive strength and tensile strength equal to zero. The following collapse mechanisms were considered (Figure 6):

- Mechanism 1: Overturning of the lantern with rotation at the base;

- Mechanism 2: Overturning of the belfry with rotation at the base;

- Mechanism 3: Overturning of the gable of the rear façade (high altar) with rotation at the base and diagonal wedges from the lateral walls of the chancel;

- Mechanism 4: Overturning of the main façade and towers with rotation at the base;

- Mechanism 5: Overturning of the main façade with rotation at the base;

- Mechanism 6: Overturning of the southwest tower with rotation at the base in the direction perpendicular to the façade; 
- Mechanism 7: Overturning of the southwest tower with rotation at the base in the direction parallel to the façade.

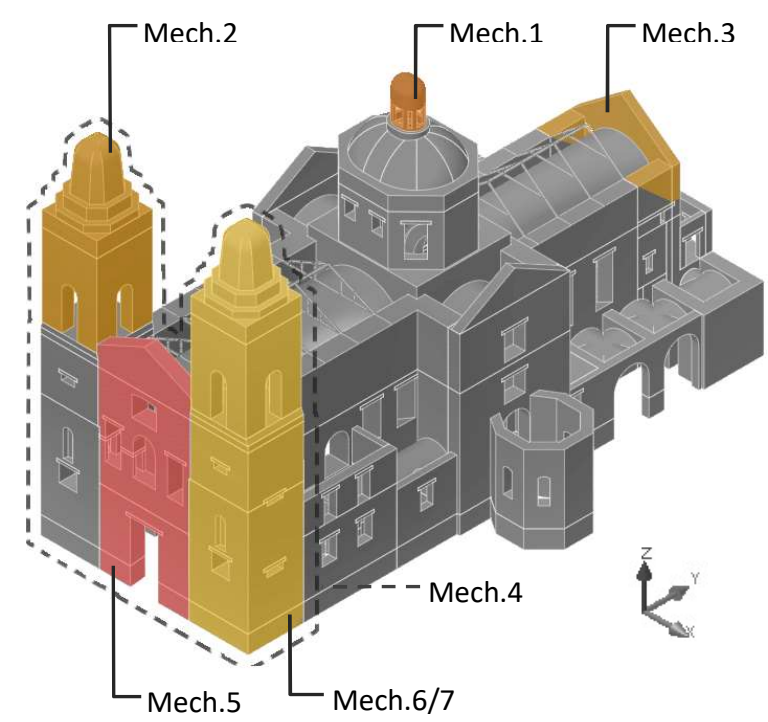

Figure 6. Collapse mechanisms considered for limit analysis

It must be noted that these collapse mechanisms were defined based on expert opinions and typical failures caused by earthquakes, which can be different from the failure modes obtained from the pushover analysis. The results of the limit analysis for the seismic action are shown in Table 3. The maximum capacity of the considered mechanisms varies between $0.09 \mathrm{~g}$ and $0.53 \mathrm{~g}$. The lowest capacity corresponds to the partial mechanism of the façade with vertical cracks in the connections with the towers. This mechanism is extremely conservative and implies a very poor connection between the longitudinal and transversal walls. There is no current damage or reasonable suspicion that indicates a poor quality connection between these walls.

Mechanism 2, which corresponds to the collapse of the belfry of the towers, has a maximum capacity of $0.48 \mathrm{~g}$, which is significantly higher than the capacity obtained from the pushover analysis in the positive longitudinal direction $(0.29$ g). However, it should be noted that the collapse obtained from the pushover analysis also involves diagonal cracks in the columns of the belfry (Figure 5b), which differs from the mechanism proposed for the limit analysis (horizontal cracks at the base of the belfry).
Mechanism 4 (overturning of façade and towers) corresponds to a failure mode also observed in the pushover analysis (Figure $5 c$ ). In this case, the maximum capacity obtained from both approaches is the same $(0.24 \mathrm{~g})$.

Finally, the limit analysis allowed to verify that the collapse mechanisms considered in this study comply with the stability criteria for seismic action defined in the Italian code NTC-08 (Table 3), with a minimum safety factor of 2.30. Disregarding Mechanism 5, the limit analysis allowed to obtain capacity values equivalent to those from the pushover analysis, despite some differences in the damage pattern associated with the mechanisms.

Table 3. Safety verification for seismic action by means of limit analysis

\begin{tabular}{|c|c|c|c|}
\hline \multirow{2}{*}{ Mechanism } & \multirow{2}{*}{$\begin{array}{c}\text { Max. } \\
\text { capacity } \\
\text { (g) }\end{array}$} & \multicolumn{2}{|c|}{ Required capacity (g) } \\
\hline & & Type 1 & Type 2 \\
\hline 1 & 0.53 & $0.08^{(B)}$ & $0.06^{(B)}$ \\
\hline 2 & 0.48 & $0.06^{(B)}$ & $0.05^{(B)}$ \\
\hline 3 & 0.31 & $0.06^{(B)}$ & $0.05^{(B)}$ \\
\hline 4 & 0.24 & $0.03^{(A)}$ & $0.04^{(A)}$ \\
\hline 5 & 0.09 & $0.03^{(A)}$ & $0.04^{(A)}$ \\
\hline 6 & 0.26 & $0.03^{(A)}$ & $0.04^{(A)}$ \\
\hline 7 & 0.25 & $0.03^{(A)}$ & $0.04^{(A)}$ \\
\hline
\end{tabular}

(A) Verification for mechanism in contact with the soil

(B) Verification for mechanism above the ground

\section{Conclusions}

A numerical model was prepared and validated to evaluate the performance and structural stability of the Church of the Monastery of São Miguel de Refojos. The seismic behavior was assessed by means of pushover analysis as well as limit analysis. Moreover, the safety condition of the structure was verified according to the prescribed criteria established in national and international codes.

In a first phase, the model was calibrated with respect to the dynamic properties estimated from the dynamic identification tests. Then, the seismic analysis allowed to conclude that the church meets the safety requirements for this type of 
action. The results showed that the negative longitudinal direction (-YY) is the most vulnerable one and is associated with the overturning mechanism of the main façade and towers with rotation at the base (out-of-plane collapse). Nonetheless, this mechanism has a safety factor equal to 3.00 .

Taking into account the results from this study, the safety condition of the structure is proven. However, and considering the aspects described in the diagnosis of the church [3], a set of preventive measures should be put into practice in order to guarantee a more efficient structural behavior and the necessary works for the conservation of the building, namely the filling of existing cracks, repair of deformed floors, and development and application of a monitoring plan including the revealing aspects for the structural behavior, such as regular visual inspection.

\section{References}

[1] Sequeira M. The Church of the Monastery of São Miguel de Refojos in Cabeceiras de Basto. In: Studies in honor of Professor José Amadeu Coelho Dias. 2006. p. 223-32. Portuguese.

[2] Lemos C, Queiroga F, Vitorino A, Melo L. Remodeling of the Cloister of the Monastery of S. Miguel de Refojos, Cabeceiras de Basto. Final Report of Archaeological Works. Perennia Monumenta; 2013. Portuguese.

[3] Lourenço PB, Mendes N, Fernandes F, Miranda T. Diagnosis of the state of conservation of the Church of the Monastery of São Miguel de Refojos de Basto. Portugal: University of Minho; 2015. Report No.: R 2015-DEC/E-29. Portuguese.

[4] DIANA FEA BV. DIsplacement method ANAlyser. Release 10. Netherlands; 2017.

[5] Italian Ministry of Infrastructures and Transportation. Circ. 02.02.2009, n. 617: Instructions for the application of the New Technical Standards for Construction referred to in the Ministerial Decree of 14 January 2008. Rome: IMIT; 2009. Italian.
[6] Vasconcelos G. Experimental investigations on the mechanics of stone masonry: characterization of granites and behavior of ancient masonry shear walls. PhD Thesis. University of Minho; 2005.

[7] Poletti E. Characterization of the seismic behaviour of traditional timber frame walls. PhD Thesis. University of Minho; 2013.

[8] Ramirez R. Structural analysis of the church of the Monastery of São Miguel de Refojos. MSc Thesis. University of Minho; 2016.

[9] Douglas BM, Reid WH. Dynamic tests and system identification of bridges. J Str Div. 1982;108(10):2295-312.

10] Ewins D. Modal testing: theory, practice and application. 2nd Ed. Baldock-Hertfordshire: Research Studies Press LTD; 2000.

[11] Tomazevic M. Earthquake-resistant and design of masonry buildings. London: Imperial College Press; 1999.

[12] CEB-FIB. Material Properties. In: CEB-FIP Model Code 90. T. Telford; 1993. p. 33-81.

[13] Lourenço PB. Recent advances in masonry modeling: Micromodeling and homogenisation. In: Multiscale modeling in solid mechanics: computational approaches. 2009. p. 251-94.

[14] Lourenço PB, Mendes N, Ramos LF, Oliveira $D$ V. Analysis of masonry structures without box behavior. Int J Archit Herit. 2011 Jul;5(4-5):369-82.

[15] EN 1998-1. Eurocode 8: Design of structures for earthquake resistance - General rules, seismic actions and rules for building. ECS; 2004.

[16] NIKER. Inventory of earthquake-induced failure mechanisms related to construction types, structural elements, and materials. POLIMI; 2010. Report No.: D 3.1.

[17] NTC-08 Guidelines. Technical Standards for Constructions. Official Journal of the Italian Republic; 2008. Italian. 